Western University Scholarship@Western

Department of Economics Research Reports

Economics Working Papers Archive

1991

\title{
Price Stability and The Monetary Order
}

David Laidler

Follow this and additional works at: https://ir.lib.uwo.ca/economicsresrpt

Part of the Economics Commons

Citation of this paper:

Laidler, David. "Price Stability and The Monetary Order." Department of Economics Research Reports, 9116. London, ON:

Department of Economics, University of Western Ontario (1991). 
ISSN : $0.318-725 \mathrm{X}$

ISBN : 0-7714-1.349-1

\author{
RESEARCH REPORT 9116 \\ PRICE STABILITY AND \\ THE MONETARY ORDER \\ by \\ David Laidier
}

November 1991

Department of Economics

Social Science Centre

University of Western Ontario

London. Ontario. Canada

N6A $5 \mathrm{C2}$

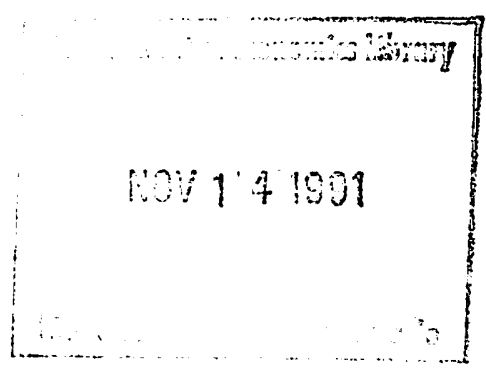




\title{
PRICE STABILITY AND THE MONETARY ORDER*
}

\author{
by
}

David Laidler

(University of Westem Ontario and C. D. Howe Institute)

*Paper presented at the Fifth International Conference of the Institute for Monetary and Economic studies of the Bank of Japan, Tokyo, October 24-25 1991. I am grateful to Peter Howitt, Angelo Melino and Allan Meltzer for helpful discussion of an earlier draft. 


\section{INTRODUCTION}

William Stanley Jevons remarked that the study of money sometimes seemed to stand in the same position to economics as that of perpetual motion to physics, or squaring the circle to mathematics. ${ }^{1}$ That was in 1874 , but the capacity of monetary economists, not always from the fringes of the discipline, to generate extraordinary ideas did not diminish in the 20th century. Whatever Keynes may have meant to tell his colleagues in the 1930s, by the 1960 s his name had become associated with the idea that government stimulus to aggregate demand, accommodated by monetary expansion, could create a permanent increase in the economy's level of output (and perhaps its rate of growth too), at a negligible cost in inflation, which was in any event largely a non-monetary phenomenon, and economically benign into the bargain. The world economy is still recovering from the great inflation which these ideas helped to create.

Monetary economics is now going through the painful process of rediscovering and refining ideas about money and inflation in the tradition that Jevons defended. The first stage of this enterprise, named by Johnson (1971) "The Monetarist counter-revolution", was largely associated with the work of Milton Friedman (eg. 1960) and Karl Brunner and and Allan Meltzer, (eg. 1963). Monetarism re-established inflation as an important policy problem, re-instated the intellectual respectability of the view that fluctuations in the value of money probably had a great deal to do with the behaviour of the supply and demand for it, and gave fresh impetus to the study of monetary policy as a means of generating price stability. Monetarism is now regarded as rather "old hat" by academic monetary theorists, but in the policy area, where it is surely more important to be right than original, many monetarist ideas are still current.

This essay, then, though critical of certain monetarist ideas, is nevertheless firmly in their tradition. It begins with a brief discussion of the desirability of price stability, defending the 
monetarist position on this matter with some rather non-monetarist arguments. It then argues that the traditional monetarist policy proposal, to achieve price stability into the indefinite future by legislating a policy rule to bind the monetary authorities once and for all, is indefensible in the face of the facts of institutional evolution in the monetary system. It goes on to develop the case that, because discretionary powers are needed to preserve price stability, the problem of designing the monetary order involves shielding those endowed with such powers from incentives to misuse them, and exposing them to incentives to behave appropriately. The "free banking" solution to this problem in institutional design is rejected as unworkable, and an alternative approach, which recognises the important role of the central bank, but emphasises the importance of ensuring its independence of short term political influence is instead defended. Finally, certain difficulties posed by the fact that central banks tend to be institutions of the nation state, while the problem of monetary stability impinges on the international economy, are explored in the light of those ideas of currency competition which also underlay the literature on free banking.

\section{THE CASE FOR PRICE STABILITY}

Monetarism re-established our understanding that inflation is a monetary phenomenon, but very little in monetarist analysis such as was expounded, for example, by Friedman (1969), enabled one to make the case that inflation did, after all, present a serious economic problem. The hypothesis that money could be treated "as if" a consumer durable good, and that the public's demand for it could be modeled as a stable function of a small number of arguments, one or more of which measured the opportunity cost of holding it, led immediately and naturally to treating inflation as a tax on money's services, and to the assessment of the social damage it might do in terms of the welfare analysis developed in the literature on public finance to measure the welfare costs of indirect taxation: inflation increased the costs of holding real balances, led to less of them being held, and the value of the services thus given 
up could be measured as the area of a triangle (or trapezium) under the demand for real balances function. This analysis applied only to fully anticipated inflation. Unanticipated variations in the purchasing power of money would, it was readily conceded, have disruptive effects on the distribution of wealth, and might, depending on one's view of the justice or otherwise of its pre-existing distribution, be regarded as costly; but since the public could be relied upon to learn how to forecast an ongoing steady inflation rate, these would not arise if inflation was stable. And although the welfare costs of fully anticipated hyper-inflation were recognised to be severe, those of moderate inflation seemed tolerable.

Monetarism did not confine its analysis of inflation anticipations to money holding behaviour. It also noted that wage and price formation processes were affected by them, and particularly when they were modelled in an adaptive, and therefore backward looking fashion, it predicted output and employment losses from any attempt to lower the anticipated inflation rate. If anticipated inflation at moderate rates imposes rather low social costs, and if attempting to remove it is expensive, it is difficult to resist the temptation to settle for living with such inflation, and to devote scarce economic talent to working on more serious (and apparently distinct) problems, such as achieving and sustaining higher growth rates. Monetarists did not take this position, but they found it hard to argue against it when others urged it upon them; and when a naive version of the forward looking rational expectations hypothesis, which predicted that the reduction of anticipated inflation would be essentially costless provided that the measure was pre-announced, failed badly in the early 1980s, their position was further weakened.

We now understand that the difficulties encountered by monetarists in earlier debates about the costs and benefits of inflation stemmed from an inadequate analysis of the role of money in economic life, and, closely related, an inadequate appreciation of just what would be involved in "anticipated" inflation. ${ }^{2}$ The "money-as-if-a-consumer-durable" analogy, so useful as a starting point for positive econometric investigation of the demand for money function, is 
hopelessly misleading when carried over to the normative analysis of inflation. It treats money as an asset which yields a purely private flow of services to the agent holding it, and in so doing abstracts from its social functions as a means of exchange and unit of account. But the private services which a stock of real balances yield to their owner are not like those to be had from a refrigerator. They are more like those yielded by a telephone which arise from the instrument being used in conjunction with a piece of public capital, namely a telecommunication network. ${ }^{3}$ Money provides services to the agents who hold it because it enables them to participate with other agents in the system of monetary exchange; and inflation not only makes it more expensive for them to hold real balances, it also undermines the efficiency of that system, particularly as a vehicle for cheaply conveying information about relative prices. Money's role as a unit of account is central here, as I shall now explain.

A "fully anticipated" inflation, so easily analysed in an abstract model economy, is not just one that agents expect, it is also one to which their behaviour is fully adapted. Thus, in a fully anticipated inflation, all contracts, all accounting systems, all taxes, and so on, are fully and continuously indexed, so that changes in the purchasing power of money affect only the own real rate of return on cash balances; and if money itself is fully indexed - a possibility that it is easy enough to conceive of in principle - then such an inflation does not even impose the simple welfare costs referred to earlier. Such a fully anticipated inflation, which underlay the monetarist analysis of the 1960s and 1970s, can, however, only occur in an economy in which money has ceased to function as a unit of account.

Because it is relative prices which matter for the operation of markets, it is unsurprising that explicit analysis of the microeconomics of price setting and contracting seems to lead to the conclusion that indexation will arise as a matter of course, and that a fully anticipated inflation will have no allocative consequences; and indeed triple and quadruple digit inflations do tend to produce the abandonment of the inflating currency as a unit of account. The recent phenomenon of "dollarisation" in Israel and a number of Latin American countries amounted 
to just that. But in the face of lower inflation rates, nevertheless quite high enough to be damaging, pre-existing arrangements are remarkably durable. Local money remains the unit of account, and indexation does not spread beyond random ad hoc arrangements. ${ }^{4}$ Price lists, tax codes, accounting practices, insurance, pension, and mortgage contracts, not to mention wage and salary agreements, continue in nominal terms long after everyone involved with them understands that the purchasing power of money is falling, is likely to continue to fall, and will profoundly affect their real implications.

When the value of money is falling, nominal prices change at discrete and unco-ordinated intervals, so that the structure of relative prices at any moment is distorted. And, though nominal interest rates adjust in the presence of inflation, this does not eliminate capital market distortions if taxes are levied on nominal interest income and on nominal capital gains, if debts continue to be discharged with constant nominal payment streams, if accounting conventions require inventories to be valued at acquisition cost, etc. Such multifarious distortions present all manner of private profit opportunities to those with special knowledge of financial and legal conventions. Human capital, like any other input, is scarce; and the more of it that is devoted to searching out and exploiting such gains, the less is available to help generate profit by other means, including the creation of new goods or better methods for producing existing ones. And human capital does not work alone. It collaborates with less skilled labour, with office space, and other physical capital to generate its output. Privately, the reallocation of scarce resources induced by inflation may be profitable, but socially it is costly. To devote resources to exploiting the private profit opportunities created by imperfectly anticipated inflation is to join, not a zero, but a negative sum game.

The upshot of all this is by now well known. There is no such thing as a fully anticipated inflation, and ongoing steady inflations are a great deal more costly than was once believed. 
Variability of the inflation rate does cause problems of its own that are well worth avoiding, and rapid inflation is more disruptive than low inflation, so that low and stable inflation is undoubtedly to be preferred to the high and variable variety. Price level stability is better yet, however, and by a significant amount, for the simple reason that it provides circumstances in which scarce resources are more likely to be devoted to increasing output and, indeed, to raising its rate of growth into the bargain. Price stability is neither necessary nor sufficient for economic growth, but it helps. Indeed, if estimates such as those of Jarrett and Selody (1982) for Canada, which suggest that a permanent one percentage point reduction in inflation is associated with a permanent one third of a percentage point increase in the rate of productivity growth, are given credence, it evidently helps a lot. And even if one regards such an estimate as implausibly high, Howitt's (1990) survey of the issues involved here shows that the cumulative value of much more modest gains can make a significant addition to any quantitative estimate of the benefits to be had from eliminating inflation.

To say that price stability is desirable, though it may be the end of one story, is merely the beginning of a number of others. For economies which are not already experiencing such a state of affairs - the United States, Canada, or the United Kingdom for example - the question must immediately arise as to whether the long term benefits of stable prices are worth the costs of achieving it. Even if any slowdown in activity is strictly temporary, lost output is lost for ever; nor can one discount $a$ priori the possibility that hysteresis effects might introduce an element of permanence into the fall in output and employment that seems to be the inevitable accompaniment to any attempt to lower inflation. This paper will not address these matters in detail. Suffice it to note that I find arguments about the high and permanent nature of the costs of even moderate inflation sufficiently convincing, and those about the likelihood of a gradualist anti-inflation policy permanently damaging the economy's productive capacity sufficiently unconvincing, that I am firmly in favour of making the move to price stability. I deal with this matter by assertion, rather than careful argument, not in order to avoid 
intellectual difficulties, but for the simple reason that another set of questions raised by the desirability of price stability, namely how to achieve and sustain it, will easily occupy the space remaining in one paper. 5

\section{THE MONEY GROWTH RULE AND DEMAND FOR MONEY INSTABILITY}

We have seen that Monetarism's identification of price stability as a desirable policy goal has been rendered much more secure by further analysis of the mechanics of inflation. Other elements of the doctrine as it stood, say twenty years ago, have fared less well. Monetarism taught that, although variations in the behaviour of the money supply could have powerful effects on the time path of real income and employment, these operated with sufficient uncertainty as to their timing - with "long and variable lags", to adopt the usual vocabulary - as to render them unhelpful for counter cyclical policy. Since it also taught that the business cycle was mainly the result of monetary impulses in the first place, however, the very avoidance of money-supply shocks was, in and of itself, a powerful stabilisation policy. A legislated quasi-constitutional rule, setting money growth at an "appropriate" rate would simultaneously achieve secular price stability and largely eliminate the cycle. To modern eyes so simple a policy doctrine appears naive.

To begin with, a pair of oil price shocks have convinced most observers, including some prominent monetarists, that though monetary impulses are often important sources of cyclical disturbance, they are far from unique. ${ }^{6}$ This observation does not undermine monetarist policy doctrines but it reduces expectations about what following them might accomplish. Stable money growth may not enable us to avoid cycles, but it could still provide a potentially powerful built in stabiliser to mitigate their severity. Or it might were it not for the instability which in the 1970s became apparent in the demand for money functions of a disturbingly large number of economies. Such instability is a potential source of cyclical disturbance in its own right, and threatens to undermine secular price level stability into the bargain. The task of 
monetary policy in its presence is to offset shifts in the demand for money with variations in the money supply, and the pursuit of price stability becomes technically an altogether more difficult matter.

I referred above to the apparent instability of demand for money functions, and my choice of this adjective was not gratuitous. As I shall now argue, the problem in question, though far from irrelevant to this paper's topic, needs to be kept in perspective. ${ }^{7}$ The relationship did not so much collapse as turn out to be rather more complicated than we had thought; and, a good deal of the problem arose from the tools we used to analyse the data, rather than with the economic processes generating them. The economic theory of the 1950 s told us quite a lot about what to expect about so-called long run, or steady state, relationships among money and the variables determining the demand for it, but it was clear from very early on that more than these long run relationships were at work in generating our data. For a while it seemed possible to deal with this issue by postulating the operation of "short-run" adjustment dynamics, whose observable consequences could be captured by modifying the long run relationship to accommodate distributed lags, often encapsulated in a single lagged dependent variable. The theoretical justification for this modification was at best flimsy and - this point is important - the accuracy of our estimates of the parameters of the underlying long-run demand function depended upon its appropriateness. In the 1970s, the data began to tell us that we had mispecified the short run demand for money function, but they did so in a way that opened up the possibility that the long run demand for money function was unstable as well. With traditional econometric methods for dealing with adjustment dynamics, one could not tell.

New techniques, involving studies of so called "co-integration", and closely related "error correction mechanisms" enable us to study the empirical properties of underlying long run relationships without having to make prior commitments to specific ways of modelling short run-adjustment dynamics. As these have been applied to data on the demand for money 
function, a number of conclusions have emerged. First, adjustment dynamics are far too complex for it to be appropriate to model them with simple regressions involving a lagged dependent variable; second we understand next to nothing about the market processes generating them; third, once adjustment dynamics are cleared out of the way, steady state relationships that look very like stable long run demand for money functions begin to re-emerge; but finally, the latter do appear to shift from time to time as a result of institutional change in the financial system. This final conclusion receives considerable corroboration from historical studies of institutional influences on the demand for money such as those of Bordo and Jonung (eg. 1990), and also from Barnett's work on aggregation (eg. 1990) which shows that, at least for the United States, Divisia aggregates whose construction takes account of the influence of institutional change on the relative liquidity of various components of monetary aggregates, appear to have more stable demand functions than do simple sum aggregates.

Each of these conclusions in turn has implications for what we can and cannot expect of monetary policy. In the 1970s, when discretionary implementation of money growth targeting (which should not be confused with adherence to a legislated money growth rule) was fashionable, the so-called short-run demand for money function was widely seen as the key to such implementation. The function in question was estimated on, say, a quarterly or even monthly basis, the values of its real income, price level, and lagged dependent variable arguments assessed, and then the one remaining argument, the rate of interest was set by the authorities in order to achieve the desired value for the left hand side variable, the money stock. When the relationship broke down, so did the possibility of accurate control of money growth by these means. Though some commentators argued that it would be more appropriate to attempt to control money growth by way of a money supply function which linked that variable to base growth by way of a money multiplier, whose empirical properties were susceptible to econometric modelling, such arguments did not convince policy makers. ${ }^{8}$ Furthermore, the fact of shifts in the long-run demand for money function meant that the 
relationship between money growth and inflation in the longer term was likely to be unreliable, so that to control money growth became less important.

With some benefit of hindsight, it is fair to say that the pervasiveness of instability in long run demand for money functions has been overstated. In some countries, for example the United States, Australia or New Zealand, the institutional change which underlay the instability in question seems to have stemmed from once and for all shifts in the regulatory environment; in others, for example the United Kingdom, it seemed to come as a response to a new policy regime; but in either case it was more of a one-off event, whose effects would in due course wear off, than a continuing source of trouble. Some countries, for example West Germany, were not afflicted with the problem at all. Others were, but without help from regulatory disturbances: about ten years ago the structure of the Canadian monetary system was markedly disturbed by the introduction of daily interest chequing accounts whose newly created feasibility seems to have been the product of advances in computer technology. ${ }^{9}$ This last example is a particularly telling one, as far as monetarist policy doctrine is concerned, since it implies that the appropriateness of any pre-legislated constant money growth rate rule is vulnerable to exogenous and unpredictable institutional change. It implies that the authorities must retain the powers necessary to adapt their policy procedures to such change as and when it occurs.

\section{THE POLITICAL ELEMENT IN MONETARY POLICY}

If it is agreed: that it is desirable to stabilise the price level; that the rate of growth of nominal money relative to that of the demand for real balances is the key to achieving this end; and that the demand for real balances function shifts around from time to time; then all that seems to be required is for the monetary authorities to monitor the latter function, to adapt nominal money growth to any shifts that occur, and to devise techniques for controlling money growth that do not rely on the stability of a short-run demand for money function. If it is also agreed 
that monetary policy should be directed to delivering price stability on average over a two or three year period, and not, say, on a quarter by quarter basis, and that it should not be given any subsidiary tasks involving attempts to stabilise real income and employment, can we not rely on the monetary authorities to deliver such an outcome?

If the fact of institutional change makes it impossible to reduce the future conduct of monetary policy to obedience to a legislatively predetermined money growth rule, that surely does not undermine a policy regime in which the authorities pursue money growth targets, but adjust them systematically in the light of new information as and when it arises. If the conduct of monetary policy was simply a matter of finding the appropriate technical means of achieving an agreed end, this conclusion would be defensible, and this paper could be brought to an end with it. ${ }^{10}$ The trouble is, though, that monetary policy is not just a technical matter. It is also a political matter. Moreover, just because there are good economic arguments for regarding the pursuit of price level stability as monetary policy's proper task does not mean that there are no others that it could conceivably be given. Nor does it mean that there are no political forces which attach value to pursuing other ends.

Earlier in this essay I noted that the traditional analysis of the costs of inflation treated them "as if" they were analogous to the welfare losses associated with an indirect tax. I argued that this treatment failed to get to the heart of the damage which inflation inflicts on a market economy; but this does not alter the fact that inflation is a source of revenue, and that the relevant authorities are, therefore, always open to the temptation to exploit it. Economic agents enjoy being the recipients of government expenditures, and dislike paying taxes. Deficit finance is always a temptation to governments seeking to maintain their popularity, and since private sector borrowers would just as soon not compete with the public sector in capital markets, so is the monetisation of deficits. To say this is platitudinous, but the point is important nevertheless; and the same may be said of the observation that monetary policy is particularly vulnerable to time inconsistency problems. Even if the trade-off between inflation 
and output is, if anything, an inverse one in the long run, so that a low inflation steady state is always preferable to a high inflation alternative, it is nevertheless probable that, on the path leading from the former to the latter, there are gains to be had on the output front. Myopic policy makers who value such gains are all too likely to opt for them; and having moved the economy to an inferior steady state they are also likely to find the return journey an unattractive one. Time inconsistency, that is to say, tends to give an inflationary bias to monetary policy, which re-inforces the temptation to use it as source of revenue. ${ }^{11}$

None of this is to say that inflation is, after all, inevitable. It is, however to say that widespread agreement about the damage that it can do, combined with the technical knowledge of how it can be avoided, do not between them provide a set of sufficient conditions to ensure that inflation will not occur. The monetarist prescription that a money growth rule be legally imposed upon the authorities stemmed not just from a desire to ensure that anti-inflation policy was technically well conducted. It also sought to address the political question of how to constrain the authorities from using their technical expertise to pursue other goals whose attainment, though privately attractive, is not in the public interest. That is why a fairly extensive literature showing that such a simple rule provides a technically sub-optimal policy regime is quite irrelevant, and why the empirical fact of money demand instability raises more than simply technical questions. As Karl Brunner (1984) noted, the analysis of monetary policy requires us to consider not just the techniques employed in its conduct, but the regime - the monetary order - within which it is implemented. The monetarist money growth rule was more than just a technical device. The proposal that it be legislated involved the specification of a particular kind of monetary order, and the conclusion that a simple legislated rule is not after all desirable must lead us to consider alternative orders, not to return to discussing monetary policy as a merely technical issue. 


\section{MORE SOPHISTICATED RULES}

To constrain by law the growth of a precisely defined monetary aggregate to a particular rate is a very specific monetary rule. If the problem with it is that institutional change might lead to the demand function for the aggregate in question, and hence its velocity of circulation, shifting over time, may it not be possible to design and legislate a more complex rule, linking the rate of money growth to the behaviour of velocity in such a way as to stabilise money income, and therefore the price level? This is the view of such analysts as Meltzer (1987) and McCallum (1988), each of whom has proposed a scheme of just this kind. One problem with feedback rules, of course, is that they may be de-stabilising. In principle, this problem can always be overcome provided one knows enough about the dynamic properties of the system to be controlled; but apparently small errors can matter a great deal. This was the fundamental message of A. W. Phillips' (eg.1954) research agenda. Meltzer and McCallum are, of course well aware of this issue, and address it by proposing that the feedback relationships built into any variable money growth rule be slow moving. This would delay the system's response to institutional change, and hence tend to make policy less effective in stabilising the price level, but it would at the same time reduce the chance of the policy rule becoming destabilising.

Meltzer and McCallum are also aware that any rule of this kind would be subject, at least in principle, to problems which usually go under the heading "Lucas Critique". That is to say, the very dynamic structure of the system which they are seeking to control might change as agents seek to adapt their behaviour to the new policy regime. There is really nothing that can be said in general about this possibility. If we were sure that we had a coherent understanding of the economy's so called fundamentals - the tastes of its inhabitants, the technology available to them, not to mention the inventory of available resources - and if we could be sure that such fundamentals were invariant, we could predict such effects and incorporate them the design of our feedback rule. But the moment one entertains doubts about the constancy of such factors, and about our capacity to foresee their future evolution, one must also start to entertain doubts 
about the durability of any analysis which treats them as given, however appropriate that might be at the time of its creation.

All this amounts to saying that the fact of unpredictable institutional change, whether policy induced or not, leads us into an infinite regress when we discuss legislated money growth rules. A constant money growth rule is inadequate, so we begin to look for a satisfactory second-level rule - a meta-rule as Brunner called it - whereby the first-level rule might be changed, but we cannot be sure about the durability of a meta-rule either. Surely the correct conclusion here is not that we should start looking for a meta-meta-rule, a rule for changing the rule governing the choice of money growth rule, but that it is in the nature of the monetary system that it cannot be locked into a particularly behaviour pattem for the indefinite future by a once and for all legislative measure enacted in the present. Though none of this is to deny that the conduct of monetary policy in many times and places might have been better if the prescriptions of Meltzer and McCallum had been followed, rather than the ad hoc measures that were in fact taken, it is to argue that their prescriptions seem to require room for someone somewhere to take discretionary actions to maintain their viability, as and when the unforeseen need arises, and that, therefore, it would be undesirable to lock them into place by legislation.

It is tempting to argue that, if perpetually binding quantity rules cannot be designed, then perhaps we should pay attention to price rules instead, not least because it is after all the price of money that we wish to stabilise. A large element of the traditional case for fixed exchange rates rests on just this premise, and it is, of course, true that an open economy which fixes the price of its domestic currency against another whose purchasing power is stable will itself tend to import price stability. ${ }^{12}$ But the injunction to maintain a fixed exchange rate on a stable currency is an incomplete policy prescription. It does not tell us how the authorities in charge of the stable foreign currency are to be induced to create that stability, nor does it lay down any procedures to be followed by the domestic authorities for recognising and reacting to any 
tendency for it to break down. Nor is a commodity based system - of which the gold standard is the archetype - proof against such problems. The purchasing power of money under such a regime is just as stable, and no more, than the relative price of the commodity upon which it is based, and as the monetary history of the late 19th century shows all too clearly, the matter is not made any simpler by the fact that the relative price in question is unlikely to be independent of the extent of monetary demands for the chosen commodity. Here as before, it is important to make the point that particular episodes in the past might have been better managed if fixed exchange rates, or a commodity standard had been in place, but it is also important to note that the adoption of an exchange rate or commodity convertibility rate does not obviate the desirability of the monetary authorities retaining discretionary authority to cope with unforeseen (and unforeseeable) eventualities.

In short, a monetary order which constrains the authorities to take only measures consistent with the pursuit of price stability has considerable attractions, but monetary institutions evolve over time, and monetary policy must be adapted as they do so. Because institutional evolution is unpredictable, the nature of that adaptation cannot be legislated in advance, and the monetary authorities must, after all, be granted discretion. To say that discretion can be misused, and has been misused, however, is not to say that it must be misused. If we cannot design a viable monetary order in which the authorities are constrained by rules to behave in an appropriate way, perhaps we can at least design one in which they are given sufficiently strong and appropriate incentives that they are likely voluntarily to deliver desirable policies. It is to consideration of this possibility that the next two sections of this paper are devoted. 


\section{FREE BANKING AS A MONETARY ORDER}

Monetary policy is by no means the only activity which, if located in the public sector, is subject to political influences which might work counter to a broader public interest. For more than two centuries economists have suggested that, in such cases, location of the activity to the private sector might be the appropriate remedy. It is this preconception that underlies the so-called "free banking" ideas to be found, for example, in Hayek's (1976) proposal for Denationalising Money, and there is a good deal to be said for them. The argument that, because the monetary system is a public good, its services must be supplied by government is, quite simply, invalid. The standard analysis of public goods suggests that if their provision is left entirely to the competitive market, a suboptimal amount will be forthcoming, but it leaves open a wide variety of possibilities for public sector intervention, other than direct govemment provision, in order to remedy the situation. No-one would deny the utility of a framework of contract and taxation law, accounting conventions, and so forth, which define the economy's unit of account, and codify social conventions about what does and does not constitute a medium for the discharge of debts. But the advocates of private money are right when they argue that it is a far cry from this to suggesting that it is the inherent job of the state directly to involve itself in the provision of the economy's means of exchange and most liquid store of value.

Indeed, if money were no more than the economy's most liquid store of value, the role it plays in most macroeconomic models formulated in Walrasian general equilibrium terms - a range that covers just about everything from Hicks's IS-LM version of Keynes to Lucas' new-classical macroeconomics - the case for its private competitive provision would be

compelling. ${ }^{13}$ The case in question rests on two considerations. The first is that any competitive industry will price its output at marginal cost. Applied to the provision of the services of liquid assets, this would involve paying the competitive rate of return on real balances, which in turn would be equal to the market rate of interest on other illiquid stores of 
value minus the marginal cost of providing liquidity. By itself, this would simply guarantee that competitively supplied real balances would bear an appropriate real rate of retum plus the expected rate of depreciation of the particular liability under analysis. However, the second consideration referred to above is that agents will wish to avoid the computational costs involved in holding assets whose real purchasing power is falling (even if their nominal rate of return is adjusted to compensate for the decline in question). This preference would ensure that only those issuers of money whose liabilities had stable purchasing power would survive.

In principle the above conclusion holds for privately issued notes as well as deposits, but like all conclusions yielded by competitive models, it rests on some rather extreme assumptions about agents' knowledge, In particular the conclusion requires that agents' costs of monitoring the soundness, and indeed the probity, of individual banks are negligible. If they are not, incentives exist for individual banks to exploit agents' ignorance by overissuing liabilities. The answer which advocates of free banking offer to this problem is more convincing in the case of deposit liabilities than currency. They argue that an overissuing bank will encounter an adverse clearing balance, and that the task of monitoring is therefore automatically transferred from non-bank agents to other banks. The mechanism here works essentially instantaneously for deposits, whose creation and utilisation by agents automatically sets the clearing mechanism to work, but might work more slowly in the case of notes, which only generate clearing problems when they are redeposited with other banks. In the 19th century, arguments like this were important in persuading legislators to pay more attention to regulating note issue than deposit banking, but in modern circumstances, where currency plays a relatively minor role in the system, they seem to me to require only a very marginal retreat on the part of advocates of free banking.

The moment we invoke the clearing mechanism as a device for disciplining competitive banks, however, we give explicit recognition to the fact that their liabilities are not only liquid stores of value, but means of exchange too, and that the inter-bank transactions which this fact 
implies also require consideration. Just as non-bank agents find it convenient to adopt a common means of exchange, money, so do banks find it convenient to settle clearing balances in a common medium, high powered money, and hold reserves of it. Also, and crucially, as Edgeworth (1888) and Wicksell (1898) showed long ago, economies of scale are inherent in the holding of reserves of high powered money, and these create incentives for banks to merge, or if diseconomies inherent in other activities work against this, at least to pool their reserves and hold them with some institution which then begins to look like a central bank. That institution in turn is a natural monopoly, which, if privately owned and unregulated will have an incentive to manage its liabilities in such a way as to generate not price level stability, but a seignorage maximising rate of inflation.

Although an unregulated and competitive banking system might well generate price level stability, then, an unregulated banking system would be extremely unlikely to remain competitive. Some centralised provision of high powered money is needed to make an otherwise competitive system viable, and the question of how its quantity ought to be regulated in order to ensure that the economy remains inflation free cannot be avoided. Suggestions by free banking advocates that the currently existing quantity of high powered money be frozen, once and for all, and the banking system otherwise be left unregulated, should be seen as attempts to come to grips with this issue by replacing a central bank with discretionary powers with a simple rule (zero growth) for the behaviour of high powered money. Such a proposal has all the attractions of any money growth rule, but also its major drawback, already discussed, namely vulnerability to the unpredictable effects of institutional change. It does not seem possible to "denationalise money" entirely, and the problem of designing monetary institutions to deliver price stability cannot be solved completely by this expedient. 


\section{CENTRAL BANK INDEPENDENCE AS A MEANS TO PRICE STABILIYY}

The matter boils down to this: price stability will not just happen; it has to be engineered by some public body; and we must devise a framework which not only confers discretionary powers on that body, but also gives it the incentives to use them in a desirable fashion. When we put it this way, it becomes clear that we are discussing not some new issue, but an old one, namely the governance of the central bank. ${ }^{14}$ The central bank, of course, is not an isolated institution, but part of the structure of government, even if, as sometimes happens, it is privately owned. Just as there is no uniquely ideal design for government which is suitable for all times and places, so too is there no optimal blueprint for a central bank that will fit all circumstances. A unitary state under parliamentary government might want to manage things in one way, a federal state where there are strong political conflicts among regions in another, and so on; but certain broad principles might nevertheless apply rather generally.

To begin with, on a purely technical level, if it is agreed that monetary policy is a matter of controlling the quantity of means of exchange available in the economy, then the central bank should have sufficient powers to do so. This in turn probably means that the economy's stock of high powered money should consist of its liabilities, and that it should be endowed with whatever powers necessary to control their volume. Also, though I am prepared to believe that it is possible to design economic models of banking systems in which system wide runs never take place, I am not prepared to believe that we shall ever be sure enough of their validity to dispense with a lender of last resort in any actual monetary system. The central bank should therefore have whatever powers are needed to fulfill this role too. Taken together, these prerequisites require that any central bank should have the authority to execute open market operations and provide rediscount facilities to commercial banks. Since all economies are open, moreover, the central bank must be able to deal in foreign exchange and foreign securities too. 
At one time it was believed that incentives to use its authority in these matters in a socially desirable fashion could be provided simply by ensuring that the central bank was privately owned, and that its directors be drawn from those segments of the community whose interest in price level stability over-rode their narrow concern with the bank's profits. ${ }^{15}$ Nowadays we understand that matters are more complicated. Regardless of whether the institution is privately or publicly owned, those running it need to be made accountable to the community at large for their activities, but the devices put in place to ensure such accountability must not simultaneously expose the central bank to the kind of political pressure which could lead it into myopic and ultimately destructive actions. As a first step, since it is hard to hold anyone accountable for their behaviour if its desired characteristics have not been clearly described before the event, this argues for giving the bank a clearly defined mandate to pursue and maintain price stability.

But a mandate alone is hardly sufficient if those who are expected to fulfill it are not insulated from pressures to set it aside. ${ }^{16}$ Thus, we must not be misled into believing that central bank accountability to the public for its performance requires that it be under the day by day control of elected politicians. On the contrary, though the central bank must clearly consult regularly with those politicians about the interaction of monetary policy with other measures for which the latter are responsible, the legal framework within which such consultations take place should make it clear that the bank's obligation to fulfill its price stability mandate takes precedence over any requirement to co-operate in the execution of other measures. It is also desirable that the bank's officials be in a position to resist pressure to do otherwise, which means that they cannot be civil servants whose terms of service require their obedience to elected politicians on pain of dismissal; rather they must serve on "good behaviour" terms, similar to those applied to the judiciary, which render their dismissal both difficult and potentially embarrassing to any politician seeking to over-ride them. Furthermore, it is important that their terms of office, and the timing of their appointments be carefully desynchronised from any electoral cycle. 
If a central bank can operate independently of the day to day pressures which routinely fall upon politicians who must make public expenditure and taxation decisions, and who are subject to the control of a sometimes myopic electorate, it is hard to see why seignorage maximisation should become one of its aims, or why it should indulge in the kind of time inconsistent inflation biased policies to which the exigencies of the electoral cycle otherwise give rise. If those running it are, moreover, ultimately accountable for fulfilling a price stability mandate, this absence of incentives to pursue inappropriate policies will be supplemented by positive incentives to behave wisely.

It is also important to understand that central bank independence does not imply that the institution's activities be shrouded in secrecy. Constant exposure to well informed and independent criticism may not be as binding as a legislated money growth rule, but it is nevertheless a potentially powerful constraint on the conduct of policy. Relevant data, then, should always be readily available, the minutes of meetings at which policy decisions are made should also be published in full and in a timely fashion, and where political institutions permit it, elected politicians should be given regular opportunities to receive reports from those in charge of monetary policy, and to question them in public about their conduct. No conceivable set of institutions will guarantee that those given discretionary power over monetary policy will always behave wisely, but a framework along the lines I have just sketched seem to offer good prospects of appropriate measures being followed.

\section{THE INTERNATIONAL DIMENSION}

Economies are open, and the efficiency of international goods and capital markets is just as dependent on a smoothly functioning international monetary system as is the efficiency of domestic markets on the stability of a national system. This paper needs to touch upon the international dimension, therefore, before it is complete. Its treatment of these matters can, 
nevertheless, be brief, given that another paper in this session, that of Professor Rogoff, is fully devoted to international monetary questions.

In an ideal world, there might exist a supra-national government, one of whose institutions might be a world central bank charged with maintaining stability in the purchasing power of a single world money. That government might have powers to ensure world-wide labour mobility in order to help particular regions to adjust to various real shocks, and the authority to address such problems by way of fiscal transfer programmes as well. That is how existing federal states manage things, and how the EEC seems to be evolving too. But there is no prospect of anything remotely resembling this coming into being on a world wide basis in the foreseeable future, and any blueprint for generating inflation-free growth in the world economy through the activities of national monetary institutions is bound to be incomplete. The best we can do is identify the gaps involved, speculate about their likely importance, and say something about which measures proposed to cope with them might help and which actually hinder, the achievement of the ultimate goal.

The first, and most obvious point to make here is that, if the central bank of an individual nation state is given a clear mandate to pursue domestic price stability, and sufficient independence of political pressures to enable it to fulfill that mandate, then it cannot simultaneously be required to stabilise its exchange rate. An international monetary order based on exchange rate flexibility between national currencies is not the result of applying any abstract optimising analysis to the system's design. Indeed, the slogan "one market, one money" would seem to point in a different direction altogether, and I shall comment on the question of optimal currency areas below. A flexible exchange rate regime is rather the natural corollory of a political order in which the highest level of reliable authority exists at the level of the nation state. At first sight, this does not seem to augur well for the future 
stability of the intemational monetary system. Experience with flexible exchange rates during the last two decades has been far from reassuring.

However, things are not as bad as they seem. The problem which the last two decades have revealed with flexible exchange rates is not that they are themselves a source of instability, but that they amplify the effects of unstable monetary policies. ${ }^{17}$ Price stability has emerged, or is emerging, as a domestic policy goal in a number of countries now, along with the recognition that it is the unique task of monetary policy to deliver it. This carries with it the promise that the major source of instability in the international monetary system is in the process of being removed. Nor is the emergence of this new concern with price stability merely fortuitous. Those same competitive forces which would drive an unregulated private banking system to emit stable valued liabilities also impinge upon central banks, particularly those of countries whose monies play an international role. They are subject to a market discipline imposed by the "currency substituting" activities of agents engaged in international transactions.

Some governments have tried hard to avoid this discipline by bringing political pressure to bear on their competitors to indulge in inflationary policies (disguised as policies to support the exchange rates of currencies in which international markets were losing confidence), but their success so far has been limited. Some central banks, notably those enjoying a relatively high degree of political independence, insisted on maintaining the purchasing power of the monies for which they are responsible; and they therefore ensured that the international co-ordination of monetary policy about which we heard so much 1980s failed. Far from being a matter for regret, this failure was most welcome. It represented the defeat of an attempt to create an international seignorage maximising cartel among central banks. Current moves towards making price stability the goal of domestic policy in a number of countries should be seen not as a new development, then, but as a continuation of a campaign against international inflationism which deserves widespread support. 
A system of flexible exchange rates among the currencies of countries enjoying domestic price stability would itself tend to produce stable exchange rate behaviour, though not necessarily constancy: productivity growth differentials among sectors of domestic economies can produce terms of trade changes within and between countries which must be absorbed by exchange rate movements if domestic price levels are stabilised. But it ought not to be claimed on this basis that getting domestic monetary policy right in enough countries is in and of itself sufficient to produce a stable international monetary order too. I have just invoked the analysis of competitive monies to help explain why price stability is becoming a popular policy goal in a number of countries, but earlier in this paper I pointed to the tendency to natural monopoly in the provision of high powered money which seems inherent in the technology of banking. This tendency is surely as present in the international monetary system as in any national framework, where it will manifest itself in a movement towards the adoption of a single money for mediating international transactions, and a tendency for agents heavily involved in international transactions to demand stability of the exchange rate of their domestic currencies against the dominant international money - the key currency as it used to be called.

The argument here is, of course, not a new one. It is simply a variation on an analytic theme which used to bear the label, "the theory of optimal currency areas". It does not therefore necessarily point to the emergence of a single dominant world money. Indeed, if the world trading order evolves towards regional blocs, one dominant currency for each bloc seems the more likely outcome. But even this possibility raises issues about the design of domestic monetary institutions which we have not yet addressed, because the boundaries of currency areas are wider than those of individual nation states. Thus the injunction to give each national central bank a mandate to deliver price stability, and to create an institutional environment in which the incentives to take this mandate seriously are maximised, to which our earlier analysis pointed, is a bit too simple. For countries whose national money is not a key currency, it does not deal with the question of how to weigh the trade-off between stabilising the domestic price level and stabilising the exchange rate on the key currency; and 
for the key currency country it does not deal with the question of how to ensure the accountability of its monetary authority across its entire area of dominance. The latter point is particularly important, because the provider of a key currency can extract seignorage from abroad. An arrangement which spreads inflation's costs across a currency area, but concentrates the revenue it can generate within the narrower jurisdiction which chooses the inflation rate, has a built in bias towards inflation. 18

The formation of a monetary union, with a single currency for the whole area is one economically feasible approach to this problem. In this case a supra-national central bank, with a mandate to deliver price stability, accountable to an electorate drawn from the whole area, but insulated from those aspects of the political process which generate resort to the inflation tax and lead to electorally driven time inconsistent policies would seem to be in order. An alternative would be to maintain national currencies linked by market determined exchange rates, thus ensuring that the market for the services of a key currency remains contestable, and hence reducing the potential seignorage to be generated from its inflation. So long as at least one central bank in the group operated under a regime in which it had no interest in maximising seignorage that would tend to discipline the rest. There are residual problems with either approach, however.

Monetary union involves a willingness to surrender a symbolically important trapping of national sovereignty, and rules out adjustment to real shocks by way of exchange rate changes. Since the possibility of international labour mobility and intemational fiscal transfers makes the latter loss less important, trading blocs which are also moving towards greater political integration - the EEC is the obvious example - are likely to find it relatively attractive. Where local political sensibilities argue against political integration - as in North America - a reliance on the mechanics of the contestable market would seem more appropriate. The danger here is the emergence of some intermediate arrangement involving pegged exchange rates. Such a system might leave the key currency country's monetary authority responsible only to its own 
electorate, make it difficult for other authorities to bring discipline to bear on it by revaluation in the face of inflation, and, most dangerous of all, might open up the possibility of elected politicians taking control of monetary policy by way of international agreements about its co-ordination within the currency area.

\section{CONCLUSIONS}

I remarked earlier that, in matters of policy, it is more important to be right than original. Thus, I make no apologies for the unspectacular conclusions which emerge from this paper. They amount to the following: price level stability is an economically desirable state of affairs, and monetary policy is the appropriate tool with which to aim for it; monetary policy has other effects on the economy too, and those in charge of it are always exposed to the temptation to misuse it; proposals to lock policy into an appropriate pattern once and for all by the enactment of some quasi-constitutional rule founder on the fact that the monetary system, like any other set of human institutions, is subject to inevitably unforeseeable change, while tendencies to natural monopoly inherent in its operation rule out a solution through the workings of a completely unregulated competitive market in the provision of money and its services; we are left, then, with relying on discretionary policy in order to maintain price stability, and the best we can do to ensure that it is properly used is to protect those in whom it is vested from incentives to do otherwise; and, given the current state of the world political and economic order, independent central banks, insulated from day to day politics, and perhaps competing with one another in the provision of international monies, seem to offer the best chance of success here.

If the chance in question is far from a certain one, and if the matter of how to preserve and improve it must therefore attract continuous attention into the foreseeable future, perhaps that 
is the best we can expect. Perhaps, indeed, the quest for a once and for all guarantee of price stability inherent in one overarching monetary reform has, after all, been uncomfortably like those for perpetual motion or a squared circle. 


\section{FOOTNOTES}

1. See the preface to Money and the Mechanism of Exchange (1874)

2. My own first effort at criticising the then orthodox analysis of inflation was prepared in 1975. See Laidler (1990 ch. 2) for a reprint of this paper. Our understanding of these matters has considerably deepened since then, and this section of this paper owes a great deal to Peter Howitt's (1990) masterly discussion of these issues.

3. But they are not identical. Two agents separated in space can benefit from a telephone system. It takes three agents (and three goods too) before monetary exchange becomes useful.

4. Stanley Fischer (1986) remains the best single source of material on the theory - not to mention practice - of indexation against inflation.

5. A comprehensive two volume collection of essays dealing with these issues in the Canadian context, but in a manner that makes them worthy of more than a national audience, is published in Richard Lipsey (ed) (1990) and Robert York (ed) (1990).

6. The locus classicus of the case for a money growth rule is Friedman (1960). Note that Brunner and Meltzer (1987) have explicitly abandoned the view that the dominant cyclical impulse is monetary in the light of the experience of the 1970s and 1980s.

7. Laidler (ed.) (1990) contains a representative selection of papers dealing with the current state of our knowledge of the demand for money function. This section of the current paper draws heavily on my editor's introduction to this volume.

8. See Johannes and Rasche (1987) for a recent empirical study of the "money" multipliers", through which base control would operate, using U. S. data. Their conclusion is that base control of money growth, at least on a quarter to quarter basis would indeed be feasible.

9. See Freedman (1983) for a detailed account of this episode.

10. And indeed an earlier essay by this author dealing with this topic did end on just such a note. See Laidler (1990, ch.7). 
11. The classic treatment of time inconsistency is, of course, Kydland and Prescott (1977). The matter is closely related to issues having to do with policy credibility. For a survey of the relevant literature see Blackburn and Christensen (1989)

12. I emphasise the word 'tend' here. Changes in the terms of trade between imports and exports can disturb the price level independently of monetary factors, and shifts in the domestic relative price structure between tradable and non-tradable goods can have similar effects; many modem applications of the purchasing power parity doctrine seem to me to pay insufficient attention to these important qualifications to its validity.

13. I am aware that it is hard indeed to give meaning to the word "liquidity" without referring to money's function as a means of exchange. I take up this matter below.

14. Pioneering empirical work on the interaction of central bank laws and the outcome of monetary policy has been carried out by my colleagues Robin Bade and Michael Parkin. Their (1987) paper builds on work which they began in the late 1970s. The argument of this section of the present paper has been much influenced by their finding that independent central banks seem, as a matter of fact, more prone to deliver stable prices than those whose conduct of monetary policy is subject to influence by politicians. Also, the discussion in the following few paragraphs about the interaction between central bank law and the incentives to which those institutions are subjected draws heavily on discussions with Peter Howitt. See also, Howitt (1991), particularly pp. 1-2.

15. These arguments were advanced by Walter Bagehot (1873) about the Bank of England, until 1945 a privately owned joint stock company govemed by a board of directors whose members came from the business community, but could not be bankers. Bagehot was far from uncritical of the Bank's performance however, but someone versed in the ideas of modern "public choice" analysis must wonder whether he was right in ascribing the Bank's failings mainly to the directors' well meaning belief in erroneous economic doctrines. 
16. Indeed Bade and Parkin (1987) find that a central bank's mandate per se has no discernable effect on its performance in the absence of political independence.

17. Note that, as long ago as (1953), Friedman made essentially the same point about the lessons of international monetary instability of the 1930s. If the argument advanced here differs at all from Friedman's it is in recognising that exchange rate behaviour can do more than reflect domestic monetary instability, but can significantly amplify its effects. The key paper dealing with this matter is, of course, Dornbusch (1976). One caveat is in order here, however. If recent work casting doubt upon the efficiency of asset markets turns out to be relevant to the foreign exchange market, then the conclusion that the only problem with flexible rates is that they amplify the effects of disturbances originating elsewhere would have to be modified. See Fortune (1991) for a survey of the relevant literature as it applies to the stock market.

18. But experience in Western Europe gives grounds for optimism on this score. The Deutschemark is certainly the key currency of the European Monetary System, but the Bundesbank's degree of political independence within Germany has enabled it to bring a good deal of stability to the whole system. Against this example, however, we must set that of the United States' role in generating inflation throughout the Bretton Woods System during the Vietnam War. Perhaps the Federal Reserve System is not, after all, as politically independent as mere inspection of its formal governance would suggest. This was the view of Weintraub (1978). 


\section{References}

Bade R. and Parkin M. (1987) "Central Bank Laws and Monetary Policy" University of Western Ontario (mimeo)

Bagehot W. (1873) Lombard Street: a Description of the Money Market London Barnett W. (1990) "Developments in Monetary Aggregation Theory" Journal of Policy

Modeling 12 (Summer) 205-58

Bordo M. and Jonung L. (1990) "The Long Run Behaviour of Velocity: the Institutional Approach Revisited" Journal of Policy Modeling 12 (Summer) 165-98

Blackburn K and Christensen M. (1989) "Monetary Policy and Policy Credibility" Journal of Economic Literature 27 (March) 1-45

Brunner K. (1984) "Monetary Policy and the Monetary Order" Aussenwirtschaft 39 and Meltzer A. H. (1963) "Predicting Velocity: Implications for Theory and Policy" Journal of Finance 18 (May) 319-54 (1987) "Money and the Economy: Issues in Monetary Analysis", the 1987 Raffaele Mattioli Lectures, Carnegie Mellon Univ. (mimeo)

Dornbusch R. (1976) "Expectations and Exchange Rate Dynamics" Journal of Political Economy 84 (Dec.) 1161-76

Edgeworth F. Y. (1888) "The Mathematical Theory of Banking" Journal of the Royal Statistical Society 51 (March) 113-26

Fischer S. (1986) Indexing, Inflation and Economic Policy Cambridge Mass., MIT Press

Fortune P. (1991) "Stock Market Efficiency: An Autopsy?" New England Economic Review (March/April) 17-40

Freedman C. (1983) "Financial Innovation in Canada: Causes and Consequences" American Economic Review 73 (May) 101-106

Friedman M (1953) "The Case for Flexible Exchange Rates" in Essays in Positive Economics Chicago, Univ. of Chicago Press (1960) A Program for Monetary Stability New York, Fordham Univ. Press (1969) The Optimum Quantity of Money, London, Macmillan. 
Hayek F. A. von (1976) Denationalising Money London, IEA

Howitt P. W. (1990) "Zero Inflation as a Long Term Target for Monetary Policy" in R. G. Lipsey (ed) 1990)

(1991) "Canadian Monetary Policy" prepared for Handbook of Monetary Policy

London, Ontario, U.W.O. (mimeo)

Jarrett P. and Selody J. (1982) "The Productivity-Inflation Nexus in Canada 1963-79" Review

of Economics and Statistics 64 (Aug.) 361-67

Jevons W. S. (1874) Money and the Mechanism of Exchange London

Johannes J. and Rasche R. (1987) Controlling the Growth of Monetary Aggregates Boston, Kluwer-Nijhoff

Johnson H. G. (1971) "The Keynesian Revolution and the Monetarist Counter-Revolution" American Economic Review 61 (May) 91-106

Kydland F. and Prescott E. (1977) "Rules rather than Discretion: the Inconsistency of Optimal Plans" Journal of Political Economy 85 (June) 473-91

Laidler D. (1990) Taking Money Seriously Cambridge Mass. MIT Press (ed) (1990) Understanding Velocity - Implications for Theory and Policy (special issue of Journal of Policy Modeling 12 (Summer)

Lipsey R. G. (ed) (1990) Zero Inflation: the Goal of Price Stability Toronto, C. D. Howe Institute.

McCallum B. T. (1988) "Robustness Properties of a Rule for Monetary Policy" in Brunner K. and McCallum B. T. (eds) Money, Cycles and Exchange Rates: Essays in Honour of Allan H. Meltzer Carnegie Rochester Conference Series Vol. 29, Amsterdam, North Holland

Meltzer A, H. (1987) "On Monetary Stability and Monetary Reform" Bank of Japan Monetary and Economic Studies 5 (Sept.) 13-34

Phillips A. W. (1954) "Stabilisation in a Closed Economy" Economic Journal 64 (June) $290-323$ 
Weintraub R. (1978) "Congressional Supervision of Monetary Policy" Journal of Monetary Economics 4 (Apr.) 341-62

Wicksell K. (1898) Interest and Prices tr. R. F. Kahn (1936) for the Royal Economic Society, London, Macmillan

York R. C. (ed) Taking Aim: the Debate on Zero Inflation Toronto, C. D. Howe Institute 